\title{
Diet composition of starry smooth-hound Mustelus asterias and methodological considerations for assessing the trophic level of predatory fish
}

\author{
Sophy R. McCully Phillips ${ }^{1,2,}{ }^{,}$, Alastair Grant ${ }^{2}$ AND Jim R. Ellis ${ }^{1}$ \\ ${ }^{1}$ Centre for Environment, Fisheries and Aquaculture Science (CEFAS), Pakefield Road, \\ Lowestoft, Suffolk, NR33 OHT, UK \\ ${ }^{2}$ School of Environmental Sciences, University of East Anglia, Norwich Research Park, \\ Norwich, Norfolk, NR4 7TJ, UK
}

*Corresponding author: sophy.phillips@cefas.co.uk; +44(0)1502 527754

The stomach contents of 640 starry smooth-hound Mustelus asterias from the Northeast Atlantic were examined. The diet was comprised primarily of crustaceans, which accounted for $98.8 \%$ index of relative importance (IRI); with the two main prey species being hermit crab Pagurus bernhardus (34\% IRI) and flying crab Liocarcinus holsatus (15\% IRI). Ontogenetic dietary preferences showed that smaller individuals $\left(20-69 \mathrm{~cm} \mathrm{~L} \mathrm{~L}_{T} ; \mathrm{n}=283\right)$ had a significantly lower diversity of prey than larger individuals $(70-124 \mathrm{~cm} \mathrm{LT} ; n=348)$; however, 18 prey species were found exclusively in smaller individuals and eight prey taxa were found exclusively in larger individuals. Larger commercially important brachyurans such as edible crab Cancer pagurus and velvet swimming crab Necora puber were more prevalent in the diet of larger individuals. Specimens from the North Sea ecoregion had a lower diversity of prey through the copyediting, typesetting, pagination and proofreading process which may lead to differences between this version and the Version of Record. Please cite this article as doi: $10.1111 / \mathrm{jfb} .14245$ 
types for a given sample size than fish from the Celtic Seas ecoregion. Whilst cumulative prey curves did not reach an asymptote, this was primarily due to the high taxonomic resolution utilised and $95 \%$ of the diet was described by just seven crustacean taxa. The trophic level (TL) was calculated as 4.34 when species-level prey categories were used. This fine-scale taxonomic resolution resulted in a TL estimate close to a whole level above that estimated using wider taxonomic groupings. This large bias has important methodological implications for TL studies based on categorised prey data, particularly those of predatory fish.

Key Words: carcinophage, cumulative prey curve, feeding ecology, Northeast Atlantic, Triakidae, trophic level

\section{$\underline{\text { Significance Statement }}$}

A full contemporary study on the dietary preferences of $M$. asterias, a species increasing in abundance and exploitation, is lacking. The breadth of the diet in relation to geographic and ontogenetic preferences is described. The trophic level estimated using a fine-scale taxonomic resolution was close to a whole level above that estimated using wider taxonomic groupings, indicating that studies based on categorised prey data could result in artificially low estimates. 


\section{INTRODUCTION}

Elasmobranchs constitute a diverse subclass displaying a broad range of feeding habits, from obligate planktivores to carnivorous apex predators consuming conspecifics and marine mammals (Wetherbee \& Cortés, 2004). An understanding of the diet and trophic levels (TL) of sharks is key in comprehending their role in the ecosystem and in understanding potential consequences to energy flux and community structure through direct (e.g. harvesting of predators) or indirect (e.g. degradation of benthic habitats through fishing) influences, which could lead to trophic cascades (reviewed in Pinnegar et al., 2000). Sharks are generally considered to be top predators with a broad-scale study of 149 species reporting a mean TL of 4.0 (range of 3.1-4.7), on par with that of marine mammals and greater than seabirds (Cortés, 1999). Cortés (1999) calculated fractional TL's of shark species by characterising their diets into eleven functional prey categories and using published TL's of these prey categories. This methodology is utilised in many studies of stomach content analysis (e.g. Ebert \& Bizzarro, 2007; Hussey et al., 2011) and is often employed due to the problems of identifying prey items to taxa level once partially digested. Other studies have used stable isotope analyses to calculate TL (Pinnegar et al., 2002; Estrada et al., 2003) rather than examining diet, or have used a comparison of the two, thus providing descriptions of feeding habits over both the short- and longer-term (Hussey et al., 2011). There is little evidence to date to show significant differences in estimated TL between the methods when applied to sharks. 
The genus Mustelus is extremely diverse with 27 valid species worldwide (Ebert et al., 2013) and new species are still being described periodically (e.g. Cubelio et al., 2011). The dietary preferences of species in this genus have been well described (Supporting Information Table S1 and S2), with dietary studies covering 18 of these species. The genus is generally reported to feed on crustaceans (primarily crabs) with some species also consuming fish. Their carcinophagus nature is also indicated by their dentition (rows of small teeth, generally molariform with some species having teeth with short erect cusps; Compagno, 1984) which is well adapted to this mode of feeding (Smale \& Compagno, 1997).

One member of this genus, starry smooth-hound Mustelus asterias Cloquet 1819, occurs on the continental shelf of the northeast Atlantic. Previous studies have documented reproductive, age, and growth parameters (Farrell et al., 2010a,b; McCully Phillips \& Ellis, 2015), however a full contemporary study on the diet of this species is lacking. Earlier dietary studies of this stock (Ford, 1921; Ellis et al., 1996) were based on limited sample sizes from restricted geographic locations. Recent increases in both relative abundance and commercial exploitation of this stock around the British Isles (see McCully Phillips \& Ellis, 2015), where this shark is one of the larger fish species in some habitats, provides the motivation for improving our understanding of this species' role within the ecosystem. This paper describes the breadth of the diet of $M$. asterias in relation to geographic and ontogenetic differences, estimates the TL of the stock, and discusses its ecological role. 


\section{MATERIALS AND METHODS}

\subsection{Dietary data}

The stomach contents of 640 specimens of $M$. asterias $\left(20-124 \mathrm{~cm}\right.$ total length, $\left.\mathrm{L}_{T}\right)$ were examined between July 2012 and August 2017. Capture locations (see McCully Phillips \& Ellis, 2015) comprised the southern North Sea (ICES Division 4.c; $n=334$ ), Celtic Sea (ICES Divisions 7.a.f-h; $n=128$ ), eastern English Channel (ICES Division 7.d; $n=92$ ) and western English Channel (ICES Division 7.e; $\mathrm{n}=86$ ).

Most samples (58\%) were sourced from commercial fishing operations, including inshore longline vessels which provided larger specimens that were either examined fresh or frozen after capture for subsequent examination. The remaining specimens (42\%) were collected opportunistically from trawl surveys on-board R.V. Cefas Endeavour, with dead specimens examined on board or frozen and examined in the laboratory.

After collection of biological parameters (including total length $L_{T}$, mass $M_{T}$, sex and maturity), the stomachs were dissected from the body cavity. The fullness of the cardiac stomach was estimated on a scale of $0-10,0$ being empty and 10 being $100 \%$ full. The contents of the cardiac stomach were then placed into a sorting tray and weighed to the nearest $0.1 \mathrm{~g}$. Contents were identified to the lowest possible taxon, either macroscopically or with a stereomicroscope, using the relevant regional taxonomic keys (Hayward \& Ryland, 1990) and 
individual prey taxa counted. Prey taxa were also scored using a points system, where scores (which totalled 10 for each specimen containing food) were allocated to each prey taxa proportionally. The stomach fullness was multiplied by the points to give a semi-quantitative index of relative prey volume (Hyslop, 1980).

The proportion of fish with empty stomachs (i.e. fullness score $=0$ ) was used to calculate the index of vacuity. These specimens and specimens with either everted stomachs or where the cardiac stomach had burst (therefore preventing the mass of stomach contents and fullness to be recorded) were excluded from further analysis.

\subsection{Data analysis}

In order to quantify the diet, the following indices were calculated for each prey taxon in the diet for all M. asterias and for each of the predator size categories:

- Frequency of occurrence $(\% \mathrm{O})$ - the percentage of all the stomachs that contained food in which each prey taxon was observed.

- Percentage by number $(\% \mathrm{~N})$ - the total number of each prey taxon as a percentage of the total number of enumerated prey items. Digested remains which could not be enumerated were given a nominal abundance of one.

- Percentage by points $(\% \mathrm{P})$ - the sum of relative prey volumes (i.e. fullness $\times$ points) for each prey taxon as a percentage of the total scores for all prey taxa.

- Index of relative importance (IRI), calculated as:

$\mid R I=(\% N+\% P) * \% O($ Pinkas et al., 1971) 
- Percentage of relative importance (\%IRI) expressed as IRI divided by the sum of all IRI, multiplied by $100(\% \mathrm{IRI}=(\mathrm{IRI} / \Sigma \mathrm{IRI}) * 100)($ Cortés, 1997)

Inanimate objects found in stomachs, such as broken shell, gravel, stone and monofilament line were recorded, but with no points or counts assigned and were only recorded as the frequency of occurrence $(\% \mathrm{~F})$ and excluded from calculations of \%IRI.

Once the diet had been quantified, additional analyses were undertaken to investigate diet preferences by size and area. The specimens were allocated to one of two size categories ( $<70$ $\mathrm{cm}, \mathrm{n}=283 ; \geq 70 \mathrm{~cm}, \mathrm{n}=348$ ), which provided broadly comparable sample sizes and also occurred at the approximate length at first maturity (McCully Phillips \& Ellis, 2015). Spatial differences in the diet were examined for the North Sea ecoregion (data from ICES Divisions 4.c and 7.d) and Celtic Seas ecoregion (data from ICES Divisions 7.a and 7.e-g). Diet composition in relation to both size and ecoregion was examined using a one-way analysis of similarities (ANOSIM) using the vegan package (Oksanen et al., 2018) in R (R Core Team, 2017). Data were square-root transformed and a Bray-Curtis dissimilarity index was used. SIMPER analyses were conducted in Primer v.5 (Clarke \& Gorley, 2001), to investigate which prey items were key to discriminate between groups. A regression was used to examine the relationship between fish mass $\mathrm{M}_{\mathrm{T}}$ and the corresponding stomach content mass.

Cumulative Prey Curves (CPCS) were carried out in R (R Core Team, 2017) using the vegan package (Oksanen et al., 2018) to determine whether the sample size adequately described 
the diet composition. Cumulative prey curves were produced for all specimens, and by geographic area (southern North Sea and eastern English Channel, and Celtic Sea and western English Channel) to determine if the diet was better described in one area compared to another.

The complete identification of dietary prey was used to estimate the TL and Levins' measure of niche breadth to assist in describing the ecological role of $M$. asterias around the UK. TL was calculated using TL values from all prey species identified (Supporting Information Table S3), or where data were unavailable using the following equation as a proxy:

$$
T L_{i}=1+\sum_{j}\left(T L_{j} . D C_{i j}\right)
$$

where $T L_{i}$ is the fractional TL of the prey $j$, and $D C_{i j}$ represents the fraction of $j$ in the diet of $i$. TL was also calculated using the same equation, but applied using the methodology of Cortés (1999), where all prey species were categorised as either 'decapod crustaceans' ( $T L=2.52)$, 'invertebrates' ( $T L=2.5)$, 'molluscs' $(T L=2.1)$ or 'cephalopods' $(T L=3.2)$.

Levins' measure of niche breadth (B) was calculated using the following formula:

$$
B=1 / \sum p^{2}
$$


where $p$ is the proportion of each prey group in the diet. The higher taxa listed in Table 1 were used as the sub-categories for calculating niche breadth. The miscellaneous and digested remains categories were removed for this purpose, and the resultant proportions of diet re-calculated accordingly.

\section{RESULTS}

In total, 640 specimens of $M$. asterias (20-124 cm LT; Figure 1) were examined and only four specimens (48-82 $\left.\mathrm{cm} \mathrm{L}_{T}\right)$ had empty stomachs leading to a low index of vacuity $=0.6 \%$. Two specimens had everted stomachs and the stomachs of a further three specimens were damaged upon extraction, thus these specimens were unable to provide data on either the mass of stomach contents or fullness. Thus, dietary data were available for 631 specimens, and these data were used for subsequent analyses.

\subsection{Diet summary}

Crustaceans comprised the main part of the diet observed, accounting for $98.8 \%$ IRI. This subphylum included a diverse range of prey taxa (49 taxa overall) with 31 identified to specieslevel. The order Decapoda was the main crustacean group predated upon (with 44 taxa identified) and the infraorder Brachyura the most species-rich prey taxa, with 17 identified to species-level or unique genus. Excluding unidentified, digested crustacean remains, the most important prey taxa were Pagurus bernhardus L. 1758 (34\% IRI, 45\% O; Table 1) and Liocarcinus holsatus (Fabricius, 1798; 15\% IRI, 25\% O). 
Fourteen categories of minor prey taxa (within the phyla Cnidaria, Mollusca, Echinodermata and class Polychaeta) were recorded. Hydroids were the best represented of these minor taxa $(2 \% \mathrm{O}, 0.04 \% \mathrm{IRI})$, with polychaetes found in $1 \%$ of stomachs $(0.01 \% \mathrm{IRI})$. Echinoderms and molluscs (excluding squid bait) were both minor taxa $(<0.01 \% \mathrm{IRI})$.

Other miscellaneous items identified within the stomach contents included broken shell, gravel, monofilament line and bait (chopped squid). There were nine records of gravel or stones in stomachs from all length classes and one incidence of monofilament line. The squid found in 33 stomachs was ingested from the bait used in the longline fishery in which they were caught, with all bar one record being from large ('mature') fish.

\subsection{Ontogenetic differences in the diet}

ANOSIM showed a significant difference between the two size-classes $(R=0.139 p=0.001)$. SIMPER analysis showed that the small size-class had (in order of magnitude) greater average abundances of unidentified crustacea, L. holsatus, Corystes cassivelaunus (Pennant 1777), Atelecyclus rotundatus (Olivi 1792) and unidentified digested remains, while $P$. bernhardus, Necora puber (L. 1767) and Cancer pagurus L. 1758 were more abundant in the diet of larger fish.

Small individuals $\left(20-69 \mathrm{~cm} \mathrm{~L}_{\mathrm{T}} ; \mathrm{n}=283\right.$ ) had a higher diversity of prey type than larger individuals, with 59 of the 68 prey categories found in their diet. However, 18 prey species were exclusive to smaller individuals; in most cases the prey type was only seen in one or two specimens, but Upogebia sp. Leach 1814, Pisidia longicornis (L. 1767), and Processa sp. Leach 
1815 , were recorded in $15(0.5 \% \mathrm{IRI})$, five and three fish respectively. The most important prey types identified to species-level, for this size-class were L. holsatus (24\% O; $13 \%$ IRI), $P$. bernhardus (23\% O; $8 \%$ IRI) and C. cassivelanus (16\% 0; 5\% IRI). Amphipods (4\% IRI) were also well represented, both in terms of numbers $(15 \% \mathrm{~N})$ and frequency of occurrence $(11 \%)$.

Larger individuals $(70-124 \mathrm{~cm} \mathrm{LT} ; \mathrm{n}=348)$ had 48 of the 68 prey categories. Eight of the identified prey taxa were found exclusively in larger individuals. The proportion of $L$. holsatus in the diet of larger individuals (25\% 0; $13 \%$ IRI) was almost identical to smaller fish. The proportion of $P$. bernhardus in the diet of large fish was, however, higher (64\% O), with this important prey taxa accounting for $58 \%$ IRI. The third most important taxa of larger fish was N. puber (17\% O; $5 \%$ IRI), a species of much less importance for smaller individuals $(0.03 \%$ IRI). Sections of squid, bait from the longline fishery, had an IRI of $1 \%$.

\subsection{Spatial differences in the diet}

Spatial differences in dietary preferences were examined by comparing fish from the two ecoregions (North Seas and Celtic Seas; Supporting Information Table S4). Whilst a greater range of prey taxa were recorded for the North Seas ecoregion $(n=54)$ than in the Celtic Seas ecoregion $(n=48)$, the sample size from the North Seas ecoregion $(n=421)$ was double that from the Celtic Seas ecoregion $(n=210)$. Indeed, there was a higher diversity of prey taxa in the Celtic Seas ecoregion than North Sea ecoregion for a given sample size. The CPCs both exhibited a similar shape without reaching an asymptote (Supporting Information Figure S1- 
2). ANOSIM found a significant difference in diet between the two ecoregions $(R=0.186, p=$ 0.001). Specimens from the North Sea had greater abundances of $P$. bernhardus, L. holsatus, unidentified digested remains and N. puber, while specimens from the Celtic Seas had greater abundances of unidentified crustacea, C. cassivelaunus, A. rotundatus and Xanthidae MacLeay 1838.

\subsection{Predation on commercial species}

Within the crustacean prey items, two commercially-important crab species were found: $N$. puber (velvet swimming crab) and C. pagurus (edible crab); overall these species were found in $10 \%$ and $7 \%$ of all stomachs respectively and accounted for $1.8 \%$ and $0.8 \%$ IRI. Thus, $N$. puber and C. pagurus were the fourth and seventh most important prey species identified. $N$. puber and C. pagurus were predominantly found in the diets of the larger size-class $(17 \%$ and $11 \%$ IRI) and were recorded mostly in specimens from the North Sea ecoregion (Supporting Information Table S4). Commercially-harvested shrimps (Crangon spp. Fabricius 1798) were a limited component of the diet (IRI's of $<1 \%)$, and no piscivory was observed.

\subsection{Cumulative prey curves}

The CPC did not reach an asymptote (Figure 2) with 68 prey categories identified in 631 fish. However, when the species were ranked by importance (\%IRI), it was apparent that $95 \%$ of 
the diet was composed of just seven prey categories and $99 \%$ by 15 categories (Figure 3). Similarly, when prey data were summed by numbers (\% N, Figure 3$)$ and the points (\% P, Figure 3), $95 \%$ of the diet was represented by 25 and 22 prey taxa respectively. The fullness/points method was considered an appropriate proxy for 'mass' (Figure 4).

\subsection{Niche breadth and trophic level}

The niche breadth of the $M$. asterias diet based on data aggregated by each of the nine subcategories, was 2.04, indicating a selective diet comprised primarily of anomuran and brachyuran decapods. The estimated TL from the Cortés (1999) methodology, using the relative proportions of just four prey categories, was 3.52. In contrast, the TL estimate based on data from all 65 prey taxa was 4.34 .

\section{DISCUSSION}

\subsection{Feeding ecology of smooth-hounds}

The genus Mustelus is species-rich genus with a circumglobal distribution. Members of the genus are morphologically similar (Compagno, 1984) and most of these species are important predators of crustaceans (Supporting Information Table S2). However, whilst most species are carcinophagous, studies on Mustelus henlei (Gill 1863) reported that squid and teleosts were the primary prey (Gomez et al., 2003; Espinoza et al., 2012; Amariles et al., 2017). Whilst most 
Mustelus spp. (including $M$. asterias) have molariform dentition, $M$. henlei have cusped teeth (Compagno, 1984). So, the degree to which the teeth of Mustelus spp. have cusps, cusplets or true molariform dentition may be an indicator of their feeding habits.

The diet of $M$. asterias, which has a molariform dentition, was found to be almost exclusively comprised of crustaceans in the present study, which supports the findings of earlier studies (Ford, 1921; Ellis et al., 1996). However, Ford (1921) recorded fish in $4.2 \%$ of stomachs ( $\mathrm{n}=$ 48) and Ellis et al. (1996) reported fish to account for $1.9 \%$ of the overall diet $(n=46)$, whilst no fish were recorded in the stomach contents in the present study, despite the much larger sample size $(n=631)$. The sampling sites for these earlier studies (Plymouth and the Irish Sea) were also sampled in the present study, with the current study also including a broader length range $(20-124 \mathrm{~cm})$ than examined by Ellis et al. $(1996 ; 43-100 \mathrm{~cm}$; size data not provided by Ford (1921)). Consequently, neither a size-related bias or regional differences would account for the absence of fish in the present study, which may be related to prey availability.

There has been a well-documented increase in regulatory discarding of marine fish over recent decades, with an estimated 1 million tonnes of marine organisms annually being discarded back into the North Sea alone (Tasker et al., 2000). The additional availability of carrion on which scavengers can prey may have been beneficial to many such species, including the crustaceans L. holsatus and P. bernhardus (Groenewold \& Fonds, 2000), the two most important prey species for $M$. asterias identified in this study. It is possible that fishing practices have provided important food resources for fish species that either scavenge 
directly or feed on invertebrate scavengers (Olaso et al., 1998). These data were collected prior to the full implementation of the demersal landings obligation, however, it is likely that once this management measure is in full force, it could negatively impact the availability and abundance of some prey taxa that are currently important in the diet.

Predation on non-crustacean taxa was limited and, in some instances, may simply have resulted from accidental ingestion. For example, various hydroids were observed, often cooccurring with certain crustaceans such as spider crab (Majidae, Samouelle 1819), Xantho spp. Leach 1814 and Liocarcinus pusillus (Leach 1816), which often associate with hydroids (e.g. Zintzen et al., 2008). The possibility that some cryptic prey were missed or underrepresented in this study is possible, however this risk is also present when using DNA metabarcoding due to primer bias (Alberdi, 2017). There were limited records of polychaetes in the diet and this coupled with the dentition supporting a carcinophagus diet, we believe that softer bodied prey were not under-represented in this study.

Molecular approaches are very beneficial in determining the presence of prey species that are digested rapidly, however, the exoskeletons of crustaceans are more resilient to digestion and thus can be used for identification beyond digestion times of soft tissues. There is also the possibility of these methods over-estimating prey taxa through secondary consumption, which along with cannibalism, is nearly impossible to detect (Nielsen et al., 2017), yet can be a significant potential source of error (Sheppard et al., 2005). Furthermore, dietary metabarcoding data often contain biases such that there exists high uncertainty around 
quantitative estimates and in many instances biomass of prey cannot be inferred (Deagle et al., 2019; Lamb et al., 2019), whereas the relative fullness and frequency of occurrence methods are favoured and recommended for the standardisation of feeding studies for their ability to discern relative prey diversity and abundance (Amundsen \& Sánchez-Hernández, 2019).

The index of vacuity was found to be very low in the present study $(0.6 \%)$, which contrasts with values up to $59 \%$ reported for other Mustelus spp. (Supporting Information Table S2). The abundance and diversity of crustaceans in the diet, combined with their lower energetic contents and slower digestion rates compared to fish prey (Blaber \& Bulman, 1987; Heupel \& Bennett, 1998), may result in the more common occurrence of such prey, thereby resulting in low indices of vacuity for crustacean feeders.

\subsection{Ontogenetic and regional differences in the diet of $M$. asterias}

There were significant $(p=0.001)$ differences between the diets of juvenile and subadult/adult $M$. asterias, which may relate to differences in gape, jaw structure and dentition (e.g. Wilga et al., 2016). Larger individuals were found with larger crustaceans more commonly in their stomachs, including P. bernhardus and N. puber, whilst smaller M. asterias had smaller swimming crabs (e.g. L. pusillus) and other small crustaceans such as P. longicornis and amphipods more commonly in their diet. This ontogenetic dietary difference could be an important parameter to recognise in size-structured ecosystem models. Many multispecies models developed for northern European seas (e.g. Araujo et al., 2005; Mackinson \& 
Daskalov, 2007) have combined 'sharks' under a single category. As ecosystem models develop, more discrete ecosystem components will be included requiring relevant speciesand size-specific dietary data, especially as such models generally have explicit categories for commercially important shellfish such as edible crab (which was found to be an important prey species).

Mustelus asterias from both ecoregions were primarily carcinophagous but significant differences in the diet were observed, which may be described by some minor differences in characteristic prey types. The diet of $M$. asterias from the Celtic Seas ecoregion was dominated by brachyuran crabs while those in the North Sea showed a prevalence of anomuran crabs ( $P$. bernhardus). This is likely a consequence of prey availability rather than dietary preferences, given the higher diversity of benthic invertebrates, including crustaceans, in the south-west compared to the southern North Sea (Rees et al., 2009; Ellis et al., 2007).

\subsection{Predation on commercial crustaceans}

The frequency in the diet of $M$. asterias of commercially fished crustaceans (N. puber and $C$. pagurus) is particularly notable. Whilst the overall role of these species was only $1.83 \%$ and $0.80 \%$ IRI respectively, the corresponding values for the larger size category were $4.58 \%$ and $1.90 \%$ IRI. Furthermore, individual samples processed over the course of the study demonstrated that $M$. asterias could consume many individuals of these species $(n \leq 6)$, highlighting that $M$. asterias may be a locally important predator. Consequently, further 
studies on the occurrence and feeding habits of $M$. asterias on important habitats of these crab species could usefully be undertaken.

There was no observed predation on Nephrops norvegicus (L. 1758) during this study, however, few if any M. asterias specimens were captured close to the muddy Nephrops grounds, and most specimens were from areas of sand and gravel sediments. Whilst most of the crustaceans consumed were mobile epifaunal species, various burrowing species (e.g. Rissoides desmaresti (Risso 1816), Alpheus glaber (Olivi 1792), Thalassinoidea Latreille 1831 and Goneplax rhomboides (L. 1758)) were found occasionally, indicating that burrowing crustaceans can be an important part of the diet. Given the increasing catch rates of $M$. asterias around the British Isles, further studies to determine whether they are important predators on Nephrops grounds could usefully be undertaken, given that other demersal sharks can also be predators of N. norvegicus (Symonds \& Elson, 1983).

\subsection{Cumulative prey curves}

The use of CPCs in dietary studies is an important method for ensuring that sample sizes are adequate for describing the diet of a species. However, in many instances the combining of prey taxa into more generic taxonomic groups may result into an artificial finding of the asymptote being reached (Silva-Garay et al., 2018). In this study, a large range of crustaceans were identified to species-level, and the CPC (including all 68 prey categories) did not reach an asymptote, despite the large sample size. It is evident that this is due to the finer-scale taxonomic resolution used, which is required to provide a more detailed and robust 
description of the breadth of diet. We propose that cumulative $\%$ IRI is a more informative metric to determine whether sample sizes are appropriate for quantifying the diet. In the present study $95 \%$ of the diet of $M$. asterias was ascribed to just seven prey taxa and $99 \%$ by 15 prey categories. This dietary preference was also reflected by the low niche breadth (2.04) which indicated a selective diet despite the large number of prey categories ( $n=68)$ observed. Given the diversity of many crustacean taxa and that the exoskeletons are slow to digest (therefore allowing their identification) dietary studies of carcinophagus fish may report a large number of species which can result in cumulative prey curves not reaching an asymptote. Furthermore, the broad spatial and temporal extent of sample collection may have also allowed for a broader range of prey taxa to be observed.

\subsection{Trophic level}

The TL calculated for M. asterias (4.34) was greater than that calculated in previous studies by Cortés (1999; 3.7), Cotter et al. (2008; 3.9), and Pinnegar et al. (2002; 4.0). These differences seem to be a result of the higher taxonomic resolution of stomach contents used in the present study, with items identified and assigned a TL by species rather than by higher taxonomic group (e.g. crustaceans and fish). Cortés (1999) summarised data from two studies with a total of 72 specimens, breaking down the diet into crustaceans, fish, cephalopods and invertebrates. Applying this methodology to our data resulted in an estimated TL of 3.52, nearly a complete level lower than the species-based estimate of this study. The greatest 
contributor to this difference was that the average crustacean TL used by Cortés $(1999 ; 2.52)$ was lower than most of those given in the literature for the various crustacean taxa (mean = 3.03, Supporting Information Table S3). The TL of Mustelus species examined in Cortés (1999) ranged from 3.5-4.2, with Mustelus californicus Gill 1864 and Mustelus palumbes Smith 1957, both TL 3.5, best representing the predominantly carcinophagic diet of $M$. asterias. Hussey et al. (2011) also reported that published TLs derived from stomach content analysis are likely to be underestimated when using functional prey categories for large predators. In their case the broad prey category of 'cephalopods' underestimated the TL calculated for Sphyrna lewini (Griffith \& Smith 1834).

Where identification of prey items beyond broad categories is not possible, it may be preferable to estimate TL using stable isotopes. Pinnegar et al. (2002) and Cotter et al. (2008) calculated TL from nitrogen stable isotope analyses and provided estimates more akin, albeit still lower than the present study. As Domi et al. (2005) alluded to, the use of stable isotopes is beneficial in describing feeding habits over the longer-term (when muscle tissue is used), as calculations are based on assimilated rather than just ingested food. However, Estrada et al. (2003) found no statistical difference between TL derived from stable isotope analysis and those calculated using diet data (from Cortés, 1999) for five shark species.

It is therefore recommended that, where possible, studies estimating TL using data from stomach content analyses apply the highest taxonomic resolution available, in order to reduce the likelihood of TL being underestimated. Augmenting traditional diet analyses 
(which provides a more detailed understanding of prey composition) with stable isotope analyses of a range of tissues would provide another metric to allow direct comparison of the diet across the short- and long-term, which could be of considerable importance in wideranging species, such as $M$. asterias.

\section{ACKNOWLEDGEMENTS}

Authors are grateful to all those involved in collecting samples. This work was funded by the

Department for Environment Food and Rural Affairs (Defra) and Cefas Seedcorn project (DP227W). We thank the editor and the anonymous reviewers for their constructive comments.

\section{SUPPORTING INFORMATION}

Additional supporting information may be found online including:

Figure S1: Cumulative prey curve for North Sea samples.

Figure S2: Cumulative prey curve for Celtic Sea samples.

Table S1: Taxonomic list of Mustelus spp. and summary of published studies on their diets

Table S2: Summary of the feeding habits of Mustelus spp.

Table S3: Trophic level of prey taxa 
Table S4. Diet composition of M. asterias around the British Isles, showing \% occurrence, \% numbers, \% points, IRI and \%IRI for fish from the North Sea ecoregion and Celtic Seas ecoregion.

\section{LITERATURE CITED}

Alberdi, A., Aizpurua, O., Gilbert, M. T. P. \& Bohmann, K. (2018) Scrutinizing key steps for reliable metabarcoding of environmental samples. Methods in Ecology and Evolution 9, $134-147$.

Amariles, D. F., Navia, A. F. \& Giraldo, A. (2017) Food resource partitioning of the Mustelus lunulatus and Mustelus henlei (Elasmobranchii: Carcharhiniformes). Environmental Biology of Fishes 100, 717-732.

Amundsen, P-A., Sánchez-Hernández, J. (2019) Feeding studies take guts - critical review and recommendations of methods for stomach contents analysis in fish. Journal of Fish Biology 95, 1364- 1373.

Araújo, J. N., Mackinson, S., Ellis, J. R. \& Hart, P. J. B. (2005) An Ecopath model of the western English Channel ecosystem with an exploration of its dynamic properties. Science Series Technical Reports, CEFAS, Lowestoft, 125; 45 pp. 
Belleggia, M., Figueroa, D. E., Sánchez, F. \& Bremec, C. (2012) The feeding ecology of Mustelus schmitti in the southwestern Atlantic: geographic variations and dietary shifts. Environmental Biology of Fishes 95, 99-114.

Blaber, S. J. M. \& Bulman, C. M. (1987) Diets of fishes of the upper continental slope of eastern Tasmania: content, calorific values, dietary overlap and trophic relationships. Marine Biology 95, 345-356.

Bulman, C., Althaus, F., He, X., Bax, N. J. \& Williams, A. (2001) Diets and trophic guilds of demersal fishes of the south-eastern Australian shelf. Marine and Freshwater Research $52,537-548$.

Capitoli, R. R., Ruffino, M. L. \& Vooren, C. M. (1995) Alimentação do tubarão Mustelus schmitti (Springer 1940) na plataforma costeira do estado do Rio Grande do Sul, Brasil. Atlântica 17, 109-122.

Chiaramonte, G. E. \& Pettovello, A. D. (2000) The biology of Mustelus schmitti in southern Patagonia, Argentina. Journal of Fish Biology 57, 930-942.

Clarke, K. R. \& Gorley, R. N. (2001). PRIMER v5: User Manual/Tutorial. Plymouth.

Coleman, N. \& Mobley, M. (1984) Diets of commercially exploited fish from Bass Strait and adjacent Victorian waters, south-eastern Australia. Australian Journal of Marine and Freshwater Research 35, 549-560. 
Cortés, E. (1997) A critical review of methods of studying fish feeding based on analysis of stomach contents: application to elasmobranch fishes. Canadian Journal of Fisheries and Aquatic Sciences 54, 726-738.

Cortés, E. (1999) Standardized diet compositions and trophic levels of sharks. ICES Journal of Marine Science 56, 707-717.

Cotter, J., Rogers, S., Ellis, J., Mackinson, S., Dulvy, N., Pinnegar, J., Jennings, S., \& Greenstreet, S. (2008) Marine Ecosystem Integrity: Development of a Marine Trophic Index for UK waters and recommendations for further indicator development. Cefas contract report C3140. Final report for Natural Environment Group, Science Division, Defra, Bristol, UK (CRO 382).

Cubelio, S. S., Remya, R. \& Kurup, B. M. (2011) A new species of Mustelus (Family: Triakidae) from Indian EEZ. Indian Journal of Geo-Marine Sciences 40, 28-31.

Ebert, D. A., Fowler, S. L. \& Compagno, L. J. (2013) Sharks of the world: a fully illustrated guide. Wild Nature Press.

Deagle, B. E., Thomas, A. C., McInnes, J. C., Clarke, L. J., Vesterinen, E. J., Clare, E. L., Kartzinel, T. R. \& Eveson, J. P. (2019) Counting with DNA in metabarcoding studies: How should we convert sequence reads to dietary data? Molecular Ecology 28, 391- 406. 
Domi, N., Bouquegneau, J. M. \& Das, K. (2005) Feeding ecology of five commercial shark species of the Celtic Sea through stable isotope and trace metal analysis. Marine Environmental Research 60, 551-569.

Ebert, D. A. \& Bizzarro, J. J. (2007) Standardized diet compositions and trophic levels of skates (Chondrichthyes: Rajiformes: Rajoidei). Environmental Biology of Fishes 80, 221237.

Ellis, J. R., Maxwell, T., Schratzberger, M., Warr K. and Rogers S. I. (2007) Small-scale heterogeneity in the mobile macro-epifauna associated with mud, sand and coarse habitats. ICES CM 2007/A:07, 17 pp.

Ellis, J. R., Pawson, M. G. \& Shackley, S. E. (1996) The comparative feeding ecology of six species of shark and four species of ray (Elasmobranchii) in the north-east Atlantic. Journal of the Marine Biological Association of the United Kingdom 76, 89-106.

Espinoza, M., Clarke, T. M., Villalobos-Rojas, F. \& Wehrtmann, I. S. (2012) Ontogenetic dietary shifts and feeding ecology of the rasptail skate Raja velezi and the brown smoothhound shark Mustelus henlei along the Pacific coast of Costa Rica, Central America. Journal of Fish Biology 81, 1578-1595.

Estrada, J. A., Rice, A. N., Lutcavage, M. E. \& Skomal, G. B. (2003) Predicting trophic position in sharks of the north-west Atlantic Ocean using stable isotope analysis. Journal of the Marine Biological Association of the United Kingdom 83, 1347-1350. 
Farrell, E. D., Mariani, S. \& Clarke, M. W. (2010a) Reproductive biology of the starry smoothhound shark Mustelus asterias: geographic variation and implications for sustainable exploitation. Journal of Fish Biology 77, 1505-1525.

Farrell, E. D., Mariani, S. \& Clarke, M. W. (2010b) Age and growth estimates for the starry smoothhound (Mustelus asterias) in the northeast Atlantic Ocean. ICES Journal of Marine Science 67, 931-939.

Filiz, H. (2009) Diet composition of smooth-hound, Mustelus mustelus (Linnaeus, 1758), in Aegean Sea, Turkey. Belgian Journal of Zoology 139, 81-84.

Fredriksen, S. (2003) Food web studies in a Norwegian kelp forest based on stable isotope ( $\delta 13 C$ and $\delta 15 N$ ) analysis. Marine Ecology Progress Series 260, 71-81.

Gelsleichter, J., Musick, J. A. \& Nichols, S. (1999) Food habits of the smooth dogfish, Mustelus canis, dusky shark, Carcharhinus obscurus, Atlantic sharpnose shark, Rhizoprionodon terraenovae, and the sand tiger, Carcharias taurus, from the northwest Atlantic Ocean. Environmental Biology of Fishes 54, 205-217.

Goldshmidt, O., Galil, B., Golani, D., Lazar, B., Erez, J. \& Baranes, A. (1995) Food selection and habitat preferences in deep-sea fishes of the northern Red Sea. In Deep-sea and extreme shallow-water habitat: affinities and adaptations (F. Uiblein, J. Ott and M. Stachowtisch, Eds.). Biosystematics and Ecology Series 11, 271-298. 
Gómez, G., Zapata, L. A., Franke, R. \& Ramos, G. E. (2003) Hábitos alimentarios de Mustelus lunulatus y $M$. henlei (Pisces: Triakidae) colectados en el Parque Nacional Natural Gorgona, Pacífico colombiano. Boletín de Investigaciones Marinas y Costeras 32, 219231.

Gračan, R., Mladineo, I. \& Lazar, B. (2014) Insight into the diet composition and gastrointestinal parasite community of the common smooth-hound, Mustelus mustelus (Carcharhiniformes: Triakidae), in the northern Adriatic Sea. Natura Croatica 23, 35-44.

Groenewold, S. \& Fonds, M. (2000) Effects on benthic scavengers of discards and damaged benthos produced by the beam-trawl fishery in the southern North Sea. ICES Journal of Marine Science 57, 1395-1406.

Hayward, P. J. and Ryland, J. S. (Eds.) (1990). The marine fauna of the British Isles and NorthWest Europe, 2 volumes. Clarendon Press, Oxford, 996 pp.

Heupel, M. R. \& Bennett, M. B. (1998) Observations on the diet and feeding habits of the epaulette shark, Hemiscyllium ocellatum (Bonnaterre), on Heron Island Reef, Great Barrier Reef, Australia. Marine and Freshwater Research 49, 753-756.

Holmes, J. M. C., Costello, M. J. \& Connor, D. W. (1997) Crustacea. In The Species Directory of the Marine Fauna and Flora of the British Isles and Surrounding Seas (C. M. Howson \& B. E. Picton, Eds.). Ulster Museum and the Marine Conservation Society: 142-209 
Hussey, N. E., Dudley, S. F. J., McCarthy, I. D., Cliff, G. \& Fisk, A. T. (2011) Stable isotope profiles of large marine predators: viable indicators of trophic position, diet and movement in sharks? Canadian Journal of Fisheries and Aquatic Sciences 68, 2029-2045.

Hyslop, E. J. (1980). Stomach contents analysis - a review of methods and their application. Journal of Fish Biology 17, 411-429.

Jardas, I., Šantić, M., Nerlović, V. \& Pallaoro, A. (2007a) Diet composition of blackspotted smooth-hound, Mustelus punctulatus (Risso, 1826), in the eastern Adriatic Sea. Journal of Applied Ichthyology 23, 279-281.

Jardas, I., Šantić, M., Nerlović, V. \& Pallaoro, A. (2007b) Diet of the smooth-hound Mustelus mustelus (Chondrichthyes: Triakidae) in the eastern Adriatic Sea. Cybium 31, 459-464.

Kamura, S. \& Hashimoto, H. (2004) The food habits of four species of triakid sharks, Triakis scyllium, Hemitriakis japanica, Mustelus griseus and Mustelus manazo, in the central Seto Inland Sea, Japan. Fisheries Science 70, 1019-1035.

King, K. J. \& Clark, M. R. (1984) The food of rig (Mustelus lenticulatus) and the relationship of feeding to reproduction and condition in Golden Bay. New Zealand Journal of Marine and Freshwater Research 18, 29-42.

Lamb, P.D., Hunter, E., Pinnegar, J. K., Creer, S., Davies, R. G. \& Taylor, M. I. (2019) How quantitative is metabarcoding: A meta-analytical approach. Molecular Ecology 28, 420 430. 
Lipej, L., Mavric, B., Rešek, S., Cherif, M. \& Capape, C. (2011) Food and feeding habits of the blackspotted smooth-hound, Mustelus punctulatus (Elasmobranchii: Carcharhiniformes: Triakidae), from the northern Adriatic. Acta Ichthyologica et Piscatoria 41, 171-177.

Mackinson, S. \& Daskalov, G. (2007) An ecosystem model of the North Sea to support an ecosystem approach to fisheries management: description and parameterisation. Science Series Technical Report, 142: 196pp.

Molina, J. M. \& Cazorla, A. L. (2011) Trophic ecology of Mustelus schmitti (Springer, 1939) in a nursery area of northern Patagonia. Journal of Sea Research 65, 381-389.

Montemarano, J. J., Havelin, J. \& Draud, M. (2016) Diet composition of the smooth dogfish (Mustelus canis) in the waters of Long Island, New York, USA. Marine Biology Research $12,435-442$.

Moreno-Sanchez, X. G., Escobar-Sánchez, O., Abitia-Cardenas, L. A., Cruz-Escalona, V. H. (2012) Diet composition of the sicklefin smooth-hound shark Mustelus lunulatus caught off El Pardito Island, Baja California Sur, Mexico. Marine Biodiversity Records 5.

Morte, S., Redon, M. J. \& Sanz-Brau, A. (1997) Feeding habits of juvenile Mustelus mustelus (Carcharhiniformes, Triakidae) in the western Mediterranean. Cahiers de Biologie Marine 38, 103-107. 
Navia, A. F., Giraldo, A. \& Mejía-Falla, P. A. (2006) Notas sobre la biología y dieta del toyo vieja (Mustelus lunulatus) en la zona central de pesca del Pacífico colombiano. Investigaciones Marinas 34, 217-222.

Navia, A. F., Mejía-Falla, P. A. \& Giraldo, A. (2007) Feeding ecology of elasmobranch fishes in coastal waters of the Colombian Eastern Tropical Pacific. BMC Ecology 7: 8.

Nielsen, J. M., Clare, E. L., Hayden, B., Brett, M. T. \& Kratina, P. (2018) Diet tracing in ecology: Method comparison and selection. Methods in Ecology and Evolution 9, 278291.

Nilsen, M., Pedersen, T., Nilssen, E. \& Fredriksen, S. (2008) Tropic studies in a high-latitude fjord ecosystem-a comparison of stable isotope analyses $\left(\delta^{13} \mathrm{C}\right.$ and $\left.\delta^{15} \mathrm{~N}\right)$ and tropic-level estimates from a mass-balance model. Canadian Journal of Fisheries and Aquatic Sciences 65, 2791-2806.

Oksanen, J., Blanchet, F. G., Friendly, M., Kindt, R., Legendre, P., McGlinn, D., Minchin, P. R., O'Hara, R. B., Simpson, G. L., Solymos, P., Stevens, M. H. H., Szoecs, E. \& Wagner, H. (2018) vegan: Community Ecology Package. R package version 2.5-2. https://CRAN.Rproject.org/package=vegan

Olaso, I., Velasco, F. \& Pérez, N. (1998) Importance of discarded blue whiting (Micromesistius poutassou) in the diet of lesser spotted dogfish (Scyliorhinus canicula) in the Cantabrian Sea. ICES Journal of Marine Science 55, 331-341. 
Pinkas, L. M., Oliphant, S. \& Iverson, I. L. K. (1971) Food habits of albacore, bluefin tuna and bonito in Californian waters. California Fish and Game 152, 1-105.

Pinnegar, J. K., Jennings, S., O’Brien, C. M. \& Polunin, N. V. C. (2002) Long-term changes in the trophic level of the Celtic Sea fish community and fish market price distribution. Journal of applied ecology 39, 377-390.

Pinnegar, J. K., Polunin, N. V. C., Francour, P., Badalamenti, F., Chemello, R., HarmelinVivien, M. L., Hereu, B., Milazzo, M., Zabala, M., d'Anna, G. \& Pipitone, C. (2000) Trophic cascades in benthic marine ecosystems: lessons for fisheries and protected-area management. Environmental Conservation 27, 179-200.

R Core Team (2017) R: A language and environment for statistical computing. R Foundation for Statistical Computing, Vienna, Austria. URL https://www.R-project.org/.

Rees, H. L., Pendle, M. A., Waldock, R., Limpenny, D. S., and Boyd, S. E. (1999) A comparison of benthic biodiversity in the North Sea, English Channel, and Celtic Seas. ICES Journal of Marine Science, 56: 228-246.

Rodríguez-Romero, J., Álvarez-Bauman, E., Ochoa-Díaz, M. R., López-Martínez, J. \& Maldonado-García, M. (2013) Feeding habits of Mustelus henlei on the western coast of Baja California Sur, México. Revista de Biología Marina y Oceanografía 48, 261-271. 
Rojas, J. R. (2006) Reproducción y alimentación del tiburón enano Mustelus dorsalis (Pisces: Triakidae) en el Golfo de Nicoya, Costa Rica: Elementos para un manejo sostenible. Revista de Biología Tropical 54, 861-971.

Rountree, R. A. \& Able, K. W. (1996) Seasonal abundance, growth, and foraging habits of juvenile smooth dogfish, Mustelus canis, in a New Jersey estuary. Fishery Bulletin 94, $522-534$.

Russo, R. A. (1975) Observations on the food habits of leopard sharks (Triakis semifasciata) and brown smoothhounds (Mustelus henlei). California Fish and Game 61, 95-103.

Saïdi, B., Bradaï, M. N. \& Bouaïn, A. (2009a) Reproductive biology and diet of Mustelus punctulatus (Risso, 1826) (Chondrichthyes: Triakidae) from the Gulf of Gabès, central Mediterranean Sea. Scientia Marina 73, 249-258.

Saïdi, B., Enajjar, S., Bradaï, M. N. \& Bouaïn, A. (2009b) Diet composition of smooth-hound shark, Mustelus mustelus (Linnaeus, 1758), in the Gulf of Gabès, southern Tunisia. Journal of Applied Ichthyology 25(S1), 113-118.

Sanchez de Benites, G., Alamo, A. \& Fuentes, H. (1983) Alteraciones en la dieta alimentaria de algunos peces comerciales por efecto del fenómeno "El Niño". In “El Niño": Su impacto en la fauna marina (W. Arntz, A. Landa and J. Tarazona, Eds.). Boletín Instituto del Mar del Peru, Volumen Extraordinario, 135-142. 
Sheppard, S. K., Bell, J., Sunderland, K. D., Fenlon, J., Skervin, D. \& Symondson, W. O. C. (2005) Detection of secondary predation by PCR analyses of the gut contents of invertebrate generalist predators. Molecular Ecology 14, 4461-4468.

Silva-Garay, L., Pacheco, A. S. \& Vélez-Zuazo, X. (2018) First assessment of the diet composition and trophic level of an assemblage of poorly known chondrichthyans off the central coast of Peru. Environmental Biology of Fishes 101, 1525-1536.

Simpfendorfer, C. A., Goodreid, A. \& McAuley, R. B. (2001) Diet of three commercially important shark species from Western Australian waters. Marine and Freshwater Research 52, 975-985.

Smale, M. J. \& Compagno, L. J. V. (1997) Life history and diet of two southern African smoothhound sharks, Mustelus mustelus (Linnaeus, 1758) and Mustelus palumbes Smith, 1957 (Pisces: Triakidae). South African Journal of Marine Science 18, 229-248.

Soto, J. (2001) Distribution and reproductive biology of the striped smooth-hound Mustelus fasciatus (Garman, 1913) (Carcharhiniformes, Triakidae). Mare Magnun 1, 129-134.

Springer, S. \& Lowe, R. H. (1963) A new smooth dogshark, Mustelus higmani, from the Equatorial Atlantic coast of South America. Copeia 1963, 245-251.

Symonds, D. J. \& Elson, J. M. (1983) The food of selected fish species on Nephrops grounds in the western Irish Sea. ICES CM 1983/K:8, 14 pp. 
Tagliafico, A., Hernández-Ávila, I., Rangel, S. \& Rago, N. (2015) Size of catch, reproduction and feeding of the small-eye smooth-hound, Mustelus higmani (Carcharhiniformes: Triakidae), in Margarita Island, Venezuela. Scientia Marina 79, 443-452.

Talent, L. G. (1982) Food habits of the gray smoothhound, Mustelus californicus, the brown smoothhound, Mustelus henlei, the shovelnose guitarfish, Rhinobatos productus, and the bat ray, Myliobatis californica, in Elkhorn Slough, California. California Fish and Game 68, 224-234.

Tasker, M. L., Camphuysen, C. J., Cooper, J., Garthe, S., Montevecchi, W. \& Blaber, S. (2000) The impacts of fishing on marine birds. ICES Journal of Marine Science 57, 531-547.

Taniuchi, T., Kuroda, N. \& Nose, Y. (1983) Age, growth, reproduction and food habits of the star-spotted dogfish, Mustelus manazo, collected from Choshi. Bulletin of the Japanese Society of Scientific Fisheries 49, 1325-1334.

Taylor, D. L., Kutil, N. J., Malek, A. J. \& Collie, J. S. (2014) Mercury bioaccumulation in cartilaginous fishes from Southern New England coastal waters: contamination from a trophic ecology and human health perspective. Marine Environmental Research 99, 2033.

Vianna, M., Arfelli, C. A. \& Amorim, A. F. (2000) Feeding of Mustelus canis (Elasmobranchii, Triakidae) caught off south-southeast coast of Brazil. Boletim do Instituto de Pesca 26, 79-84. 
Wetherbee, B. M. \& Cortés, E. (2004) Food consumption and feeding habits. In Biology of Sharks and their Relatives (J. C. Carrier, J. A. Musick and M. R. Heithaus, Eds.). CRC Press, 232-253.

White, W. \& Last, P. (2006) Description of two new species of smooth-hounds, Mustelus widodoi and M. ravidus (Carcharhiniformes: Triakidae) from the western central Pacific. Cybium 30, 235-246.

Wilga, C. A., Diniz, S. E., Steele, P. R., Sudario-Cook, J., Dumont, E. R. \& Ferry, L. A. (2016) Ontogeny of feeding mechanics in smoothhound sharks: morphology and cartilage stiffness. Integrative and Comparative Biology 56, 442-448.

Yamaguchi, A. \& Taniuchi, T. (2000) Food variations and ontogenetic dietary shift of the starspotted-dogfish Mustelus manazo at five locations in Japan and Taiwan. Fisheries Science 66, 1039-1048.

Zintzen, V., Norro, A., Massin, C. \& Mallefet, J. (2008) Temporal variation of Tubularia indivisa (Cnidaria, Tubulariidae) and associated epizoites on artificial habitat communities in the North Sea. Marine Biology 153, 405-420. 


\section{Significance Statement}

A full contemporary study on the dietary preferences of $M$. asterias, a species increasing in abundance and exploitation, is lacking. The breadth of the diet in relation to geographic and ontogenetic preferences is described. The trophic level estimated using a fine-scale taxonomic resolution was close to a whole level above that estimated using wider taxonomic groupings, indicating that studies based on categorised prey data could result in artificially low estimates.

This article is protected by copyright. All rights reserved. 
Table 1: Diet composition of M. asterias around the British Isles, showing \% occurrence, $\%$ numbers, $\%$ points, IRI and \%IRI for juvenile ( $<70 \mathrm{~cm})$, subadult and adult ( $\geq 70$ $\mathrm{cm}$, and all specimens.

\begin{tabular}{|c|c|c|c|c|c|c|c|c|c|c|c|c|c|c|c|c|c|c|c|c|c|c|c|c|c|}
\hline i... er taxa & Prey taxa & & & all Size $C$ & ss (20 & $9 \mathrm{~cm}:$ & = 283) & & & & & e Size Cl & is $(70-$ & $24 \mathrm{~cm}:$ & $=348$ ) & & & & & All fish & $0-124$ & $n: n=$ & & & \\
\hline & & $\begin{array}{c}\begin{array}{c}\text { Count } \\
\text { of }\end{array} \\
\text { stomac } \\
\text { hs with } \\
\text { prey } \\
\text { type } \\
\text { present }\end{array}$ & $\begin{array}{c}\text { Sum of } \\
\text { numbe } \\
\text { rs of } \\
\text { each } \\
\text { prey } \\
\text { type }\end{array}$ & $\begin{array}{l}\text { Sum } \\
\text { of } \\
\text { Fullne } \\
\text { ss } x \\
\text { Points }\end{array}$ & $\% 0$ & $\% \mathrm{~N}$ & $\% P$ & IRI & \%IRI & 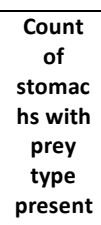 & $\begin{array}{c}\text { Sum of } \\
\text { numbe } \\
\text { rs of } \\
\text { each } \\
\text { prey } \\
\text { type }\end{array}$ & $\begin{array}{l}\text { Sum } \\
\text { of } \\
\text { Fullne } \\
\text { ss } x \\
\text { Points }\end{array}$ & $\% 0$ & $\% \mathrm{~N}$ & $\% \mathrm{P}$ & IRI & \%IRI & 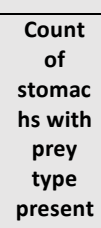 & $\begin{array}{c}\text { Sum of } \\
\text { numbe } \\
\text { rs of } \\
\text { each } \\
\text { prey } \\
\text { type }\end{array}$ & $\begin{array}{c}\text { Sum } \\
\text { of } \\
\text { Fullne } \\
\text { ss } x \\
\text { Points }\end{array}$ & $\% 0$ & $\% \mathrm{~N}$ & \%P & IRI & \%IRI \\
\hline Cnidarla & Tubularia sp. & & & & & & & & & 1 & 1 & 4 & 0.29 & 0.08 & 0.03 & 0.03 & 0.00 & 1 & 1 & 4 & 0.16 & 0.04 & 0.01 & 0.01 & 0.00 \\
\hline & $\begin{array}{l}\text { Hydrallmania } \\
\text { falcata }\end{array}$ & & & & & & & & & 1 & 1 & 5 & 0.29 & 0.08 & 0.03 & 0.03 & 0.00 & 1 & 1 & 5 & 0.16 & 0.04 & 0.02 & 0.01 & 0.00 \\
\hline & Hydroida (indet.) & 7 & 9 & 41 & 2.47 & 0.88 & 0.26 & 2.82 & 0.06 & 6 & 6 & 24 & 1.72 & 0.46 & 0.16 & 1.07 & 0.02 & 13 & 15 & 65 & 2.06 & 0.65 & 0.21 & 1.76 & 0.04 \\
\hline & Cnidaria & & & & & & & & 0.06 & & & & & & & & 0.02 & & & & & & & & 0.04 \\
\hline Polychaeta & Arenicola sp. & 1 & 1 & 15 & 0.35 & 0.10 & 0.10 & 0.07 & 0.00 & & & & & & & & & 1 & 1 & 15 & 0.16 & 0.04 & 0.05 & 0.01 & 0.00 \\
\hline & Polychaeta (indet.) & 6 & 6 & 45 & 2.12 & 0.58 & 0.29 & 1.85 & 0.04 & 1 & 1 & 7 & 0.29 & 0.08 & 0.05 & 0.04 & 0.00 & 7 & 7 & 52 & 1.11 & 0.30 & 0.17 & 0.52 & 0.01 \\
\hline & Polychaeta & & & & & & & & 0.04 & & & & & & & & 0.00 & & & & & & & & 0.01 \\
\hline & $\begin{array}{l}\text { Rissoides } \\
\text { desmaresti }\end{array}$ & & & & & & & & & 2 & 2 & 41 & 0.57 & 0.15 & 0.27 & 0.24 & 0.00 & 2 & 2 & 41 & 0.32 & 0.09 & 0.13 & 0.07 & 0.00 \\
\hline & Idotea linearis & 3 & 3 & 89 & 1.06 & 0.29 & 0.57 & 0.92 & 0.02 & 4 & 10 & 57 & 1.15 & 0.77 & 0.37 & 1.31 & 0.02 & 7 & 13 & 146 & 1.11 & 0.56 & 0.47 & 1.15 & 0.02 \\
\hline & $\begin{array}{l}\text { Gammarellus } \\
\text { homari }\end{array}$ & 1 & 1 & 8 & 0.35 & 0.10 & 0.05 & 0.05 & 0.00 & & & & & & & & & 1 & 1 & 8 & 0.16 & 0.04 & 0.03 & 0.01 & 0.00 \\
\hline & Amphipoda & 32 & 151 & 418 & $\begin{array}{r}11.3 \\
1\end{array}$ & $\begin{array}{r}14.6 \\
9\end{array}$ & 2.69 & $\begin{array}{r}196.5 \\
1\end{array}$ & 3.91 & 1 & 1 & 3 & 0.29 & 0.08 & 0.02 & 0.03 & 0.00 & 33 & 152 & 421 & 5.23 & 6.55 & 1.36 & 41.37 & 0.88 \\
\hline $\begin{array}{l}\text { Decapda- } \\
\text { Caride }\end{array}$ & Palaemon sp. & & & & & & & & & 2 & 2 & 24 & 0.57 & 0.15 & 0.16 & 0.18 & 0.00 & 2 & 2 & 24 & 0.32 & 0.09 & 0.08 & 0.05 & 0.00 \\
\hline & Alpheus glaber & 1 & 3 & 80 & 0.35 & 0.29 & 0.51 & 0.29 & 0.01 & & & & & & & & & 1 & 3 & 80 & 0.16 & 0.13 & 0.26 & 0.06 & 0.00 \\
\hline & Processa sp. & 3 & 3 & 29 & 1.06 & 0.29 & 0.19 & 0.51 & 0.01 & & & & & & & & & 3 & 3 & 29 & 0.48 & 0.13 & 0.09 & 0.11 & 0.00 \\
\hline & $\begin{array}{l}\text { Pandalina } \\
\text { brevirostris }\end{array}$ & 2 & 3 & 18 & 0.71 & 0.29 & 0.12 & 0.29 & 0.01 & & & & & & & & & 2 & 3 & 18 & 0.32 & 0.13 & 0.06 & 0.06 & 0.00 \\
\hline & Pandalus montagui & 1 & 1 & 12 & 0.35 & 0.10 & 0.08 & 0.06 & 0.00 & 1 & 1 & 6 & 0.29 & 0.08 & 0.04 & 0.03 & 0.00 & 2 & 2 & 18 & 0.32 & 0.09 & 0.06 & 0.05 & 0.00 \\
\hline & Pandalidae (indet.) & 2 & 2 & 11 & 0.71 & 0.19 & 0.07 & 0.19 & 0.00 & 1 & 1 & 4 & 0.29 & 0.08 & 0.03 & 0.03 & 0.00 & 3 & 3 & 15 & 0.48 & 0.13 & 0.05 & 0.08 & 0.00 \\
\hline & Crangon allmanni & 18 & 31 & 246 & 6.36 & 3.02 & 1.58 & 29.25 & 0.58 & 17 & 23 & 107 & 4.89 & 1.78 & 0.70 & 12.09 & 0.21 & 35 & 54 & 353 & 5.55 & 2.33 & 1.14 & 19.24 & 0.41 \\
\hline & Crangon crangon & 7 & 12 & 103 & 2.47 & 1.17 & 0.66 & 4.53 & 0.09 & 27 & 43 & 310 & 7.76 & 3.33 & 2.02 & 41.44 & 0.73 & 34 & 55 & 413 & 5.39 & 2.37 & 1.34 & 19.97 & 0.43 \\
\hline & Crangon sp. & 6 & 7 & 74 & 2.12 & 0.68 & 0.48 & 2.45 & 0.05 & 12 & 14 & 75 & 3.45 & 1.08 & 0.49 & 5.42 & 0.09 & 18 & 21 & 149 & 2.85 & 0.90 & 0.48 & 3.96 & 0.08 \\
\hline & Natantia (indet.) & 2 & 2 & 18 & 0.71 & 0.19 & 0.12 & 0.22 & 0.00 & 1 & 1 & 8 & 0.29 & 0.08 & 0.05 & 0.04 & 0.00 & 3 & 3 & 26 & 0.48 & 0.13 & 0.08 & 0.10 & 0.00 \\
\hline $\begin{array}{l}\text { Deca, da- } \\
\text { Anomura }\end{array}$ & $\begin{array}{l}\text { Callianassa } \\
\text { tyrrhena }\end{array}$ & 1 & 1 & 20 & 0.35 & 0.10 & 0.13 & 0.08 & 0.00 & & & & & & & & & 1 & 1 & 20 & 0.16 & 0.04 & 0.06 & 0.02 & 0.00 \\
\hline
\end{tabular}

This article is protected by copyright. All rights reserved. 


\begin{tabular}{|c|c|c|c|c|c|c|c|c|c|c|c|c|c|c|c|c|c|c|c|c|c|c|c|c|c|}
\hline & Upogebia stellata & 1 & 1 & 10 & 0.35 & 0.10 & 0.06 & 0.06 & 0.00 & & & & & & & & & 1 & 1 & 10 & 0.16 & 0.04 & 0.03 & 0.01 & 0.00 \\
\hline & Upogebia sp. & 15 & 19 & 493 & 5.30 & 1.85 & 3.17 & 26.61 & 0.53 & & & & & & & & & 15 & 19 & 493 & 2.38 & 0.82 & 1.59 & 5.74 & 0.12 \\
\hline & $\begin{array}{l}\text { Thalassinoidea } \\
\text { (indet.) }\end{array}$ & 4 & 5 & 85 & 1.41 & 0.49 & 0.55 & 1.46 & 0.03 & 13 & 15 & 112 & 3.74 & 1.16 & 0.73 & 7.05 & 0.12 & 17 & 20 & 197 & 2.69 & 0.86 & 0.64 & 4.04 & 0.09 \\
\hline & Anapagurus laevis & 2 & 2 & 39 & 0.71 & 0.19 & 0.25 & 0.31 & 0.01 & & & & & & & & & 2 & 2 & 39 & 0.32 & 0.09 & 0.13 & 0.07 & 0.00 \\
\hline & $\begin{array}{l}\text { Pagurus } \\
\text { bernhardus }\end{array}$ & 66 & 83 & 1317 & $\begin{array}{r}23.3 \\
2\end{array}$ & 8.07 & 8.47 & $\begin{array}{r}385.9 \\
4\end{array}$ & 7.68 & 223 & 332 & 4039 & $\begin{array}{r}64.0 \\
8\end{array}$ & $\begin{array}{r}25.6 \\
8\end{array}$ & $\begin{array}{r}26.2 \\
6\end{array}$ & $\begin{array}{r}3328 . \\
22\end{array}$ & $\begin{array}{r}58.3 \\
8\end{array}$ & 289 & 415 & 5356 & $\begin{array}{r}45.8 \\
0\end{array}$ & $\begin{array}{r}17.8 \\
8\end{array}$ & $\begin{array}{r}17.3 \\
2\end{array}$ & $\begin{array}{r}1612 . \\
28\end{array}$ & $\begin{array}{r}34.3 \\
6\end{array}$ \\
\hline & Pagurus prideaux & 3 & 3 & 39 & 1.06 & 0.29 & 0.25 & 0.58 & 0.01 & 3 & 7 & 78 & 0.86 & 0.54 & 0.51 & 0.90 & 0.02 & 6 & 10 & 117 & 0.95 & 0.43 & 0.38 & 0.77 & 0.02 \\
\hline & Paguridae (indet.) & 10 & 10 & 149 & 3.53 & 0.97 & 0.96 & 6.83 & 0.14 & 3 & 3 & 35 & 0.86 & 0.23 & 0.23 & 0.40 & 0.01 & 13 & 13 & 184 & 2.06 & 0.56 & 0.60 & 2.38 & 0.05 \\
\hline & Galathea sp. & 5 & 5 & 63 & 1.77 & 0.49 & 0.41 & 1.58 & 0.03 & & & & & & & & & 5 & 5 & 63 & 0.79 & 0.22 & 0.20 & 0.33 & 0.01 \\
\hline & Munida rugosa & & & & & & & & & 1 & 1 & 16 & 0.29 & 0.08 & 0.10 & 0.05 & 0.00 & 1 & 1 & 16 & 0.16 & 0.04 & 0.05 & 0.02 & 0.00 \\
\hline & Pisidia longicornis & 5 & 5 & 32 & 1.77 & 0.49 & 0.21 & 1.22 & 0.02 & & & & & & & & & 5 & 5 & 32 & 0.79 & 0.22 & 0.10 & 0.25 & 0.01 \\
\hline Decan & Hyas coarctatus & 1 & 1 & 14 & 0.35 & 0.10 & 0.09 & 0.07 & 0.00 & 1 & 1 & 15 & 0.29 & 0.08 & 0.10 & 0.05 & 0.00 & 2 & 2 & 29 & 0.32 & 0.09 & 0.09 & 0.06 & 0.00 \\
\hline & $\begin{array}{l}\text { Macropodia } \\
\text { rostrata }\end{array}$ & 1 & 1 & 10 & 0.35 & 0.10 & 0.06 & 0.06 & 0.00 & 2 & 2 & 15 & 0.57 & 0.15 & 0.10 & 0.14 & 0.00 & 3 & 3 & 25 & 0.48 & 0.13 & 0.08 & 0.10 & 0.00 \\
\hline & $\begin{array}{l}\text { Macropodia } \\
\text { tenuirostris }\end{array}$ & 1 & 1 & 24 & 0.35 & 0.10 & 0.15 & 0.09 & 0.00 & & & & & & & & & 1 & 1 & 24 & 0.16 & 0.04 & 0.08 & 0.02 & 0.00 \\
\hline & Macropodia sp. & 1 & 2 & 21 & 0.35 & 0.19 & 0.14 & 0.12 & 0.00 & 5 & 8 & 47 & 1.44 & 0.62 & 0.31 & 1.33 & 0.02 & 6 & 10 & 68 & 0.95 & 0.43 & 0.22 & 0.62 & 0.01 \\
\hline & Majidae (indet.) & 13 & 13 & 162 & 4.59 & 1.26 & 1.04 & 10.60 & 0.21 & 10 & 15 & 91 & 2.87 & 1.16 & 0.59 & 5.03 & 0.09 & 23 & 28 & 253 & 3.65 & 1.21 & 0.82 & 7.38 & 0.16 \\
\hline & $\begin{array}{l}\text { Corystes } \\
\text { cassivelaunus }\end{array}$ & 45 & 67 & 1283 & $\begin{array}{r}15.9 \\
0\end{array}$ & 6.52 & 8.26 & $\begin{array}{r}234.9 \\
2\end{array}$ & 4.68 & 21 & 48 & 389 & 6.03 & 3.71 & 2.53 & 37.66 & 0.66 & 66 & 115 & 1672 & $\begin{array}{r}10.4 \\
6\end{array}$ & 4.95 & 5.41 & $\begin{array}{r}108.3 \\
9\end{array}$ & 2.31 \\
\hline & $\begin{array}{l}\text { Atelecyclus } \\
\text { rotundatus }\end{array}$ & 34 & 47 & 786 & $\begin{array}{r}12.0 \\
1\end{array}$ & 4.57 & 5.06 & $\begin{array}{r}115.6 \\
9 \\
\end{array}$ & 2.30 & 28 & 41 & 508 & 8.05 & 3.17 & 3.30 & 52.09 & 0.91 & 62 & 88 & 1294 & 9.83 & 3.79 & 4.18 & 78.37 & 1.67 \\
\hline & $\begin{array}{l}\text { Bathynectes } \\
\text { longipes }\end{array}$ & 1 & 1 & 10 & 0.35 & 0.10 & 0.06 & 0.06 & 0.00 & & & & & & & & & 1 & 1 & 10 & 0.16 & 0.04 & 0.03 & 0.01 & 0.00 \\
\hline & Cancer pagurus & 4 & 4 & 69 & 1.41 & 0.39 & 0.44 & 1.18 & 0.02 & 39 & 60 & 776 & $\begin{array}{r}11.2 \\
1\end{array}$ & 4.64 & 5.05 & $\begin{array}{r}108.5 \\
5 \\
\end{array}$ & 1.90 & 43 & 64 & 845 & 6.81 & 2.76 & 2.73 & 37.41 & 0.80 \\
\hline & Carcinus maenus & 4 & 12 & 104 & 1.41 & 1.17 & 0.67 & 2.60 & 0.05 & 17 & 32 & 512 & 4.89 & 2.47 & 3.33 & 28.35 & 0.50 & 21 & 44 & 616 & 3.33 & 1.90 & 1.99 & 12.94 & 0.28 \\
\hline & $\begin{array}{l}\text { Liocarcinus } \\
\text { arcuatus }\end{array}$ & 1 & 1 & 10 & 0.35 & 0.10 & 0.06 & 0.06 & 0.00 & & & & & & & & & 1 & 1 & 10 & 0.16 & 0.04 & 0.03 & 0.01 & 0.00 \\
\hline & $\begin{array}{l}\text { Liocarcinus } \\
\text { depurator }\end{array}$ & 6 & 10 & 178 & 2.12 & 0.97 & 1.15 & 4.49 & 0.09 & 12 & 23 & 278 & 3.45 & 1.78 & 1.81 & 12.37 & 0.22 & 18 & 33 & 456 & 2.85 & 1.42 & 1.47 & 8.26 & 0.18 \\
\hline & $\begin{array}{l}\text { Liocarcinus } \\
\text { holsatus }\end{array}$ & 69 & 165 & 1742 & $\begin{array}{r}24.3 \\
8 \\
\end{array}$ & $\begin{array}{r}16.0 \\
5 \\
\end{array}$ & $\begin{array}{r}11.2 \\
1 \\
\end{array}$ & $\begin{array}{r}664.6 \\
5 \\
\end{array}$ & $\begin{array}{r}13.2 \\
3 \\
\end{array}$ & 86 & 237 & 1628 & $\begin{array}{r}24.7 \\
1 \\
\end{array}$ & $\begin{array}{r}18.3 \\
3 \\
\end{array}$ & $\begin{array}{r}10.5 \\
9 \\
\end{array}$ & $\begin{array}{r}714.5 \\
6 \\
\end{array}$ & $\begin{array}{r}12.5 \\
3 \\
\end{array}$ & 155 & 402 & 3370 & $\begin{array}{r}24.5 \\
6 \\
\end{array}$ & $\begin{array}{r}17.3 \\
2 \\
\end{array}$ & $\begin{array}{r}10.9 \\
0 \\
\end{array}$ & $\begin{array}{r}693.1 \\
8 \\
\end{array}$ & $\begin{array}{r}14.7 \\
7 \\
\end{array}$ \\
\hline & Liocarcinus pusillus & 12 & 14 & 180 & 4.24 & 1.36 & 1.16 & 10.69 & 0.21 & 1 & 1 & 4 & 0.29 & 0.08 & 0.03 & 0.03 & 0.00 & 13 & 15 & 184 & 2.06 & 0.65 & 0.60 & 2.56 & 0.05 \\
\hline & Liocarcinus sp. & 12 & 15 & 220 & 4.24 & 1.46 & 1.42 & 12.19 & 0.24 & 15 & 20 & 260 & 4.31 & 1.55 & 1.69 & 13.95 & 0.24 & 27 & 35 & 480 & 4.28 & 1.51 & 1.55 & 13.10 & 0.28 \\
\hline & Necora puber & 5 & 5 & 66 & 1.77 & 0.49 & 0.42 & 1.61 & 0.03 & 58 & 85 & 1398 & $\begin{array}{r}16.6 \\
7 \\
\end{array}$ & 6.57 & 9.09 & $\begin{array}{r}261.0 \\
6 \\
\end{array}$ & 4.58 & 63 & 90 & 1464 & 9.98 & 3.88 & 4.73 & 85.99 & 1.83 \\
\hline & Portunidae (indet.) & 7 & 8 & 217 & 2.47 & 0.78 & 1.40 & 5.38 & 0.11 & 10 & 13 & 155 & 2.87 & 1.01 & 1.01 & 5.79 & 0.10 & 17 & 21 & 372 & 2.69 & 0.90 & 1.20 & 5.68 & 0.12 \\
\hline & Monodaeus couchi & & & & & & & & & 1 & 2 & 21 & 0.29 & 0.15 & 0.14 & 0.08 & 0.00 & 1 & 2 & 21 & 0.16 & 0.09 & 0.07 & 0.02 & 0.00 \\
\hline & Pilumnus hirtellus & 2 & 2 & 28 & 0.71 & 0.19 & 0.18 & 0.26 & 0.01 & 3 & 6 & 53 & 0.86 & 0.46 & 0.34 & 0.70 & 0.01 & 5 & 8 & 81 & 0.79 & 0.34 & 0.26 & 0.48 & 0.01 \\
\hline & Xantho sp. & 1 & 1 & 10 & 0.35 & 0.10 & 0.06 & 0.06 & 0.00 & & & & & & & & & 1 & 1 & 10 & 0.16 & 0.04 & 0.03 & 0.01 & 0.00 \\
\hline & Xanthidae (indet.) & 13 & 71 & 471 & 4.59 & 6.91 & 3.03 & 45.65 & 0.91 & 12 & 36 & 222 & 3.45 & 2.78 & 1.44 & 14.58 & 0.26 & 25 & 107 & 693 & 3.96 & 4.61 & 2.24 & 27.14 & 0.58 \\
\hline
\end{tabular}




\begin{tabular}{|c|c|c|c|c|c|c|c|c|c|c|c|c|c|c|c|c|c|c|c|c|c|c|c|c|c|}
\hline & $\begin{array}{l}\text { Goneplax } \\
\text { rhomboides }\end{array}$ & 1 & 2 & 12 & 0.35 & 0.19 & 0.08 & 0.10 & 0.00 & 5 & 5 & 95 & 1.44 & 0.39 & 0.62 & 1.44 & 0.03 & 6 & 7 & 107 & 0.95 & 0.30 & 0.35 & 0.62 & 0.01 \\
\hline & Brachyura (indet.) & 7 & 7 & 247 & 2.47 & 0.68 & 1.59 & 5.62 & 0.11 & 6 & 10 & 179 & 1.72 & 0.77 & 1.16 & 3.34 & 0.06 & 13 & 17 & 426 & 2.06 & 0.73 & 1.38 & 4.35 & 0.09 \\
\hline crustacean & Crustacea (indet.) & 175 & 177 & 5323 & $\begin{array}{r}61.8 \\
4 \\
\end{array}$ & $\begin{array}{r}17.2 \\
2 \\
\end{array}$ & $\begin{array}{r}34.2 \\
5 \\
\end{array}$ & $\begin{array}{r}3182 . \\
86 \\
\end{array}$ & $\begin{array}{r}63.3 \\
6 \\
\end{array}$ & 120 & 124 & 2815 & $\begin{array}{r}34.4 \\
8 \\
\end{array}$ & 9.59 & $\begin{array}{r}18.3 \\
0 \\
\end{array}$ & $\begin{array}{r}961.8 \\
3 \\
\end{array}$ & $\begin{array}{r}16.8 \\
7 \\
\end{array}$ & 295 & 301 & 8138 & $\begin{array}{r}46.7 \\
5 \\
\end{array}$ & $\begin{array}{r}12.9 \\
7\end{array}$ & $\begin{array}{r}26.3 \\
2 \\
\end{array}$ & $\begin{array}{r}1836 . \\
76 \\
\end{array}$ & $\begin{array}{r}39.1 \\
4 \\
\end{array}$ \\
\hline \multicolumn{2}{|c|}{ Total Crustacean } & & & & & & & & $\begin{array}{r}98.7 \\
1\end{array}$ & & & & & & & & $\begin{array}{r}98.5 \\
9\end{array}$ & & & & & & & & $\begin{array}{r}98.7 \\
9 \\
\end{array}$ \\
\hline 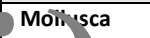 & Nucula sp. (shell) & & & & & & & & & 1 & 1 & 7 & 0.29 & 0.08 & 0.05 & 0.04 & 0.00 & 1 & 1 & 7 & 0.16 & 0.04 & 0.02 & 0.01 & 0.00 \\
\hline & Mytilus edulis & 1 & 1 & 12 & 0.35 & 0.10 & 0.08 & 0.06 & 0.00 & 1 & 1 & 1 & 0.29 & 0.08 & 0.01 & 0.02 & 0.00 & 2 & 2 & 13 & 0.32 & 0.09 & 0.04 & 0.04 & 0.00 \\
\hline & Corbula gibba & 1 & 1 & 6 & 0.35 & 0.10 & 0.04 & 0.05 & 0.00 & & & & & & & & & 1 & 1 & 6 & 0.16 & 0.04 & 0.02 & 0.01 & 0.00 \\
\hline & Bivalvia (indet.) & 2 & 3 & 37 & 0.71 & 0.29 & 0.24 & 0.37 & 0.01 & & & & & & & & & 2 & 3 & 37 & 0.32 & 0.13 & 0.12 & 0.08 & 0.00 \\
\hline & Sepiolidae & 1 & 1 & 8 & 0.35 & 0.10 & 0.05 & 0.05 & 0.00 & & & & & & & & & 1 & 1 & 8 & 0.16 & 0.04 & 0.03 & 0.01 & 0.00 \\
\hline & $\begin{array}{l}\text { Cephalopoda } \\
\text { (beak) }\end{array}$ & & & & & & & & & 1 & 1 & 12 & 0.29 & 0.08 & 0.08 & 0.04 & 0.00 & 1 & 1 & 12 & 0.16 & 0.04 & 0.04 & 0.01 & 0.00 \\
\hline \multicolumn{2}{|c|}{ Total Mollusca } & & & & & & & & 0.01 & & & & & & & & 0.00 & & & & & & & & 0.00 \\
\hline erm & Ophiura albida & 1 & 1 & 14 & 0.35 & 0.10 & 0.09 & 0.07 & 0.00 & 1 & 1 & 5 & 0.29 & 0.08 & 0.03 & 0.03 & 0.00 & 2 & 2 & 19 & 0.32 & 0.09 & 0.06 & 0.05 & 0.00 \\
\hline & Ophiura sp. & 1 & 1 & 3 & 0.35 & 0.10 & 0.02 & 0.04 & 0.00 & & & & & & & & & 1 & 1 & 3 & 0.16 & 0.04 & 0.01 & 0.01 & 0.00 \\
\hline & Echinoid & & & & & & & & & 1 & 1 & 4 & 0.29 & 0.08 & 0.03 & 0.03 & 0.00 & 1 & 1 & 4 & 0.16 & 0.04 & 0.01 & 0.01 & 0.00 \\
\hline \multicolumn{2}{|c|}{ Total Echinodermata } & & & & & & & & 0.00 & & & & & & & & 0.00 & & & & & & & & 0.00 \\
\hline aneo & Broken shell & 1 & & 0 & 0.35 & & & & & 1 & & 0 & 0.29 & & & & & 2 & & 0 & 0.32 & & & & \\
\hline & Gravel/stone & 7 & & 0 & 2.47 & & & & & 2 & & 0 & 0.57 & & & & & 9 & & 0 & 1.43 & & & & \\
\hline & Monofilament line & 1 & & 0 & 0.35 & & & & & & & & & & & & & 1 & & 0 & 0.16 & & & & \\
\hline & Squid (bait) & 1 & 1 & 35 & 0.35 & 0.10 & 0.23 & 0.11 & 0.00 & 32 & 36 & 558 & 9.20 & 2.78 & 3.63 & 58.96 & 1.03 & 33 & 37 & 593 & 5.23 & 1.59 & 1.92 & 18.37 & 0.39 \\
\hline & Digested remains & 23 & 23 & 784 & 8.13 & 2.24 & 5.05 & 59.19 & 1.18 & 18 & 18 & 377 & 5.17 & 1.39 & 2.45 & 19.88 & 0.35 & 41 & 41 & 1161 & 6.50 & 1.77 & 3.75 & 35.88 & 0.76 \\
\hline Total & hiscellaneous & & & & & & & & 1.18 & & & & & & & & 1.38 & & & & & & & & 1.16 \\
\hline
\end{tabular}

Fir re 1. Length-frequency distribution of $M$. asterias analysed (the small and large size-classes are indicated by the dashed line).

Higure 2. Cumulative prey curve for all samples $(n=631)$ by prey category.

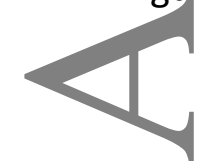

This article is protected by copyright. All rights reserved. 


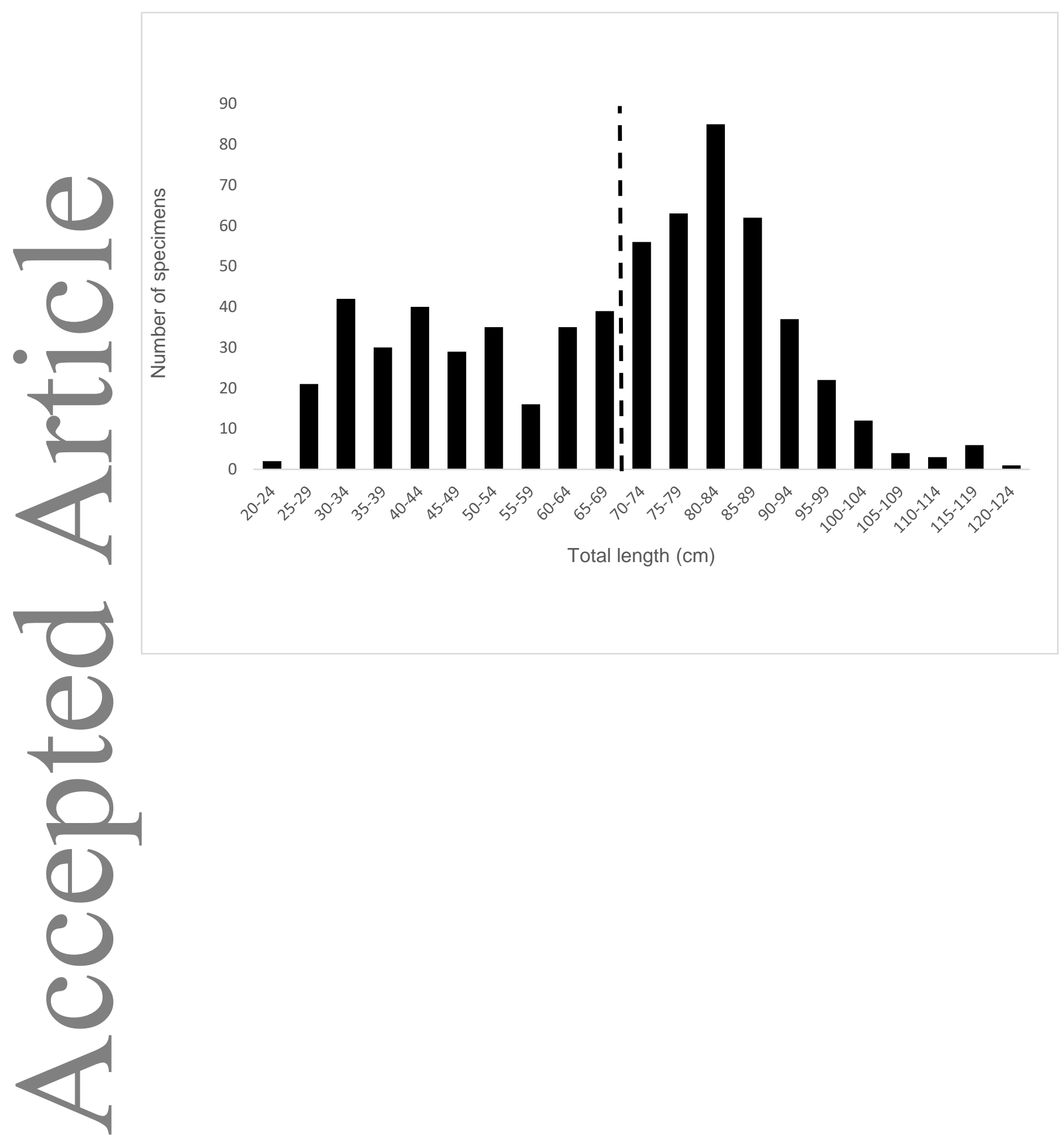




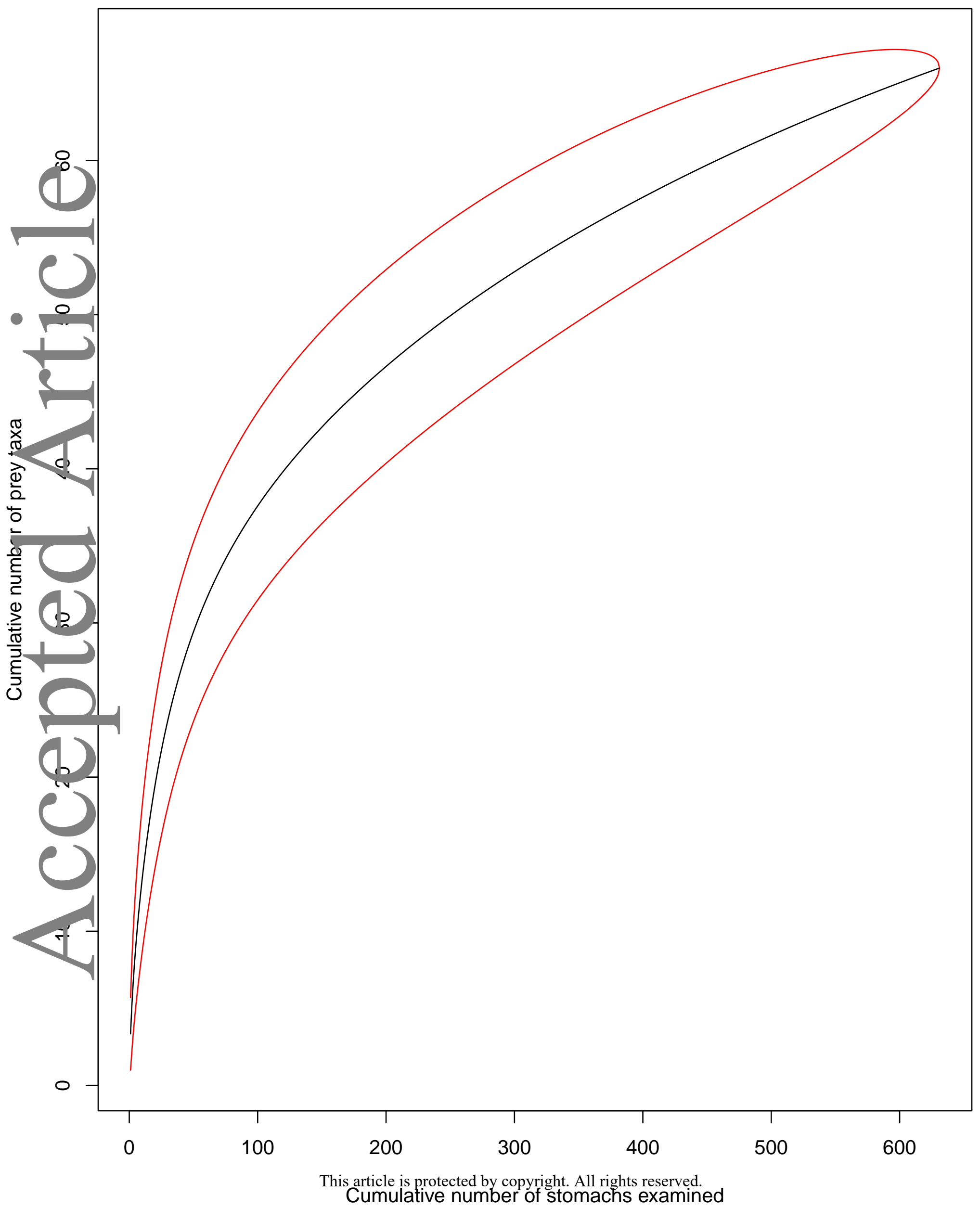


